\title{
Annamia dubia sp. nov. with a description of a new family, Geminocystaceae fam. nov. (Cyanobacteria)
}

\author{
Akihiro TujI ${ }^{1 *}$, Haruyo YAmaguCHI ${ }^{2}$, Takafumi KataOKA ${ }^{3}$, Mayumi $\mathrm{SATO}^{2}$, Tomoharu \\ $\mathrm{SANO}^{4} \&$ Yuko NIIYAMA ${ }^{1}$
}

${ }^{1}$ Department of Botany, National Museum of Nature and Sciences, Amakubo 4-1-1, Tsukuba, Ibaraki 305-0005, Japan*Corresponding authore-mail: tuji@kahaku.go.jp

${ }^{2}$ Center for Environmental Biology and Ecosystem Studies, National Institute for Environmental Studies, Ibaraki 305-8506, Japan

${ }^{3}$ Faculty of Marine Science and Technology, Fukui Prefectural University, 1-1 Gakuen-cho Obama, Fukui 917-0003, Japan

${ }^{4}$ Center for Environmental Measurement and Analysis, National Institute for Environmental Studies, Ibaraki 305-8506, Japan

\begin{abstract}
Our environmental DNA analysis identified Annamia-like operational taxonomic units (OTUs) from Lake Kasumigaura, Japan every summer season during the period from June 2012-May 2015. A strain from Lake Kasumigaura that agreed with an Annamia-like OTU (NIES-4383) was established with a cell-sorting machine. Based on the differences in morphology and 16S rRNA sequences, a new taxon is described: Annamia dubia Tuji, Yamaguchi et Niiyama sp. nov. A. dubia produces a microcystins that is also produced by A. toxica. Our 16S rRNA phylogenetical analysis reveals that the genus Annamia makes a monophyletic clade with the genera Geminocystis, Geminobacterium, and 'Cyanobacterium.' Although this clade agrees with Cyanobacteriaceae KomÁReK et al. (2014), this family is invalid based on the invalid genus Cyanobacterium and the type species Cyanobacterium stanieri. We propose the alternative name Geminocystaceae Tuji, Yamaguchi et Niiyama fam. nov. based on the genus Geminocystis.
\end{abstract}

Key words: Cyanobacteriaceae, Chroococcales, Lake Kasumigaura, Microcystin, NGS, Phylogeny, Phytoplankton

\section{INTRODUCTION}

Cyanobacteria is an important component of phytoplankton for the ecology of inland lakes and biomonitoring. The taxonomy of Japanese planktic Cyanobacteria (blue-green algae) was developed during the 1970s1990s (e.g., Kato et al. 1991; Watanabe 1992) because of the water pollution at the height of Japan's economic boom. However, the taxonomy of small-sized planktic cyanobacteria has been unclear. We have been tackling this problem and have described five Pseudanabaena taxa from Japan (Niryama et al. 2016; TUJI \& NiIYAMA 2016; TuJI \& NiIYAma 2018b). These taxa produce an odor compound (2-methylisoborneol: 2-MIB) and are important species for the management of inland waters. Since it is difficult to identify species compositions and seasonal changes with morphological observation using light microscopy and not molecular analyses (TUנI \& NiIYAMA 2018a), the precise species compositions and seasonal changes in the field are poorly understood.
Environmental DNA (eDNA) analyses using next-generation sequencing (NGS) should be a useful tool for expanding our understanding of the ecology of planktic cyanobacteria. SHIzUKa et al. (2020) examined 2-MIBproducing cyanobacteria in Japan's Lake Ogawara by conducting an eDNA analysis, and they identified $P$. cinerea Tuji et Niiyama and $P$. yagii Tuji et Niiyama from this lake. We also applied an eDNA analysis to our phytoplankton monitoring at Lake Kasumigaura, Japan during the roughly 3-year period from June 2012 to May 2015 and identified abundant Annamia-like operational taxonomic units (OTUs) from the lake. These OTUs were close to A. toxica Nguyen, which was described from Hoamy Reservoir, Vietnam (NGUYEN et al. 2013). Although the OTUs were abundant in Lake Kasumigaura, we could not find Annamia species by microscopic observation during the $1-$ year survey. We identified a strain that agreed with Annamia-like OTU, by using a cell-sorting method. We describe this newly isolated Annamia species herein and discuss the taxonomic state of genus Annamia. 


\section{Materials ANd Methods}

Abundance analyses of genus Annamia using environmental DNAs. Thirty-six water samples were taken from the surface at the sampling site $\left(36^{\circ} 02.142^{\prime} \mathrm{N}, 140^{\circ} 24.222^{\prime} \mathrm{E}\right)$ at Lake Kasumigaura from June 2012 to May 2015. The water samples were prefiltered using a $41-\mu \mathrm{m}$ pore-size nylon mesh filter (Merck Millipore) to remove large-sized zooplanktons. The filtrates were further filtered by a $0.4-\mu \mathrm{m}$ pore-size polycarbonate membrane filter. DNA extraction from the filtered cells was performed using a DNeasy Plant Mini Kit (Qiagen, Hilden, Germany) following the manufacturer's protocol.

To amplify the partial 16S rRNA gene, we used a set of primer pairs, Cyan108f (RINTA-KANTO et al. 2005) with A-adapter and each barcode sequence used in the Ion Personal Genome Machine (PGM ${ }^{\mathrm{TM}}$ ) (Thermo Fisher Scientific, Waltham, MA, USA) and 519r (TURNER et al. 1999) with a trP1 adapter. Q $5^{\circledR}$ High-Fidelity DNA Polymerase (New England Biolabs, Ipswich, MA) was used for the amplification. The libraries were separated by agarose gel electrophoresis and purified using a QIAquick gel extraction kit (Qiagen). The purified libraries were then further purified using Agencourt AMPure XP beads (Beckman Coulter, Indianapolis, IN). The quality control of the libraries was conducted using TapeStation D1000 ScreenTape (Agilent Technologies, Santa Clara, CA). The libraries were quantified using a KAPA Library Quantification Kit for Ion Torrent (Kapa Biosystems, Woburn, MA).

Next-generation sequencing was performed using the Ion PGM system with the Ion PGM Hi-Q Sequencing Kit and the Ion 318 Chip (Thermo Fisher Scientific) following the manufacturer's protocol. All of the generated sequence reads were de-multiplexed according to the index primers and processed using the software package Claident ver. 0.2.2015.03.11 (TANABE \& ToJU 2013) as described with a minor modification for the Ion PGM platform (KATAOKA et al. 2017). Briefly, the sequence reads were quality-controlled using filters that removed all of the reads containing any single mismatch or ambiguous bases in the index tag or primer sequences. Potentially chimeric sequences were then removed using VSERCH (https:/github. com/torognes/vsearch).

We used the remaining reads to establish operational taxonomic units (OTUs) using a 95\% cut-off level, and we searched the representative sequences of the obtained OTUs for the close relatives' sequences of the 16S rRNA gene from the strain Annamia toxica (GenBank ID: HQ658457) by performing a BLASTn search. Each OTU that showed $>0.1 \%$ of the average read abundance of the 36 samples were defined as an abundant OTU. The raw sequences were deposited in the DDBJ Sequence Read Archive (DRA) in the DNA Data Base of Japan (DDBJ) under accession no. DRA009964.

Sampling and establishment of the culture strain. A water sample was taken from the surface at the same sampling site in Lake Kasumigaura on Nov. 11, 2015. The raw sample water was provided for cell sorting. Cell sorting was performed using an On-chip Sort cell-sorting machine (On-chip Biotechnologies, Tokyo) equipped with a 488-nm wavelength Argon ion laser. A disposable sorting chip (2D-Z101, On-chip Biotechnologies) and AF-6 medium (KATo 1982) as a sheath buffer were used for sorting.

First, 201 cells were sorted from a sorting gate under the condition of high chlorophyll and side scatter, and they were diluted to a 96-well plate with AF-6 medium. One month later, a strain was established from a single well that contained a filamentous cyanobacterium, and the strain was then transferred into MA medium (ICHIMURA 1979). The strain was maintained under a light intensity of 11-14 $\mu \mathrm{mol}$ photons. $\mathrm{m}^{-2} \cdot \mathrm{s}^{-1}$ with a light cycle of 10:14 (light:darkness). This strain is available for the public from the culture collection of National Institute for Environmental Studies as strain number NIES-4383 (NIES, http://mcc.nies.go.jp/).

Transmission electron microscopy (TEM). Strain NIES4383 were cultivated for 30 days under the above-described conditions. Samples sandwiched between copper disks were frozen in liquid propane at $-175{ }^{\circ} \mathrm{C}$. Once the samples were frozen, they were freeze-substituted with $2 \%$ glutaraldehyde, $1 \%$ tannic acid in $100 \%$ ethanol, and $2 \%$ distilled water in $100 \%$ ethanol at $-80{ }^{\circ} \mathrm{C}$ for 2 days. The samples were then maintained at $-20^{\circ} \mathrm{C}$ for $3 \mathrm{hr}$, followed by a warm-up to $4^{\circ} \mathrm{C}$ for $4 \mathrm{hr}$. The samples were dehydrated though ethanol three times for 30 min each. After these dehydration processes the samples were continuously dehydrated with ethanol at room temperature overnight.

The samples were infiltrated with propylene oxide two times for $30 \mathrm{~min}$ each and then placed in a 70:30 mixture of propylene oxide and resin (Quetol-812; Nissin EM Co., Tokyo) in tubes for $1 \mathrm{hr}$. The caps of the tubes in which the samples were places were left open, and propylene oxide was volatilized overnight. Next, the samples were transferred to a fresh $100 \%$ resin and polymerized at $60^{\circ} \mathrm{C}$ for $48 \mathrm{hr}$. The polymerized resins were ultra-thin-sectioned at $70 \mathrm{~nm}$ with a diamond knife and an ultramicrotome (Ultracut UCT; Leica, Venna, Austria), and the sections were mounted on copper grids. They were stained with $2 \%$ uranyl acetate at room temperature for $15 \mathrm{~min}$ and washed with distilled water and then secondary-stained with Lead Stain solution (Sigma-Aldrich, Tokyo) at room temperature for $3 \mathrm{~min}$. The grids were observed by a transmission electron microscope (JEM-1400Plus; JEOL, Tokyo) at an acceleration voltage of $100 \mathrm{kV}$. Digital images were taken with a CCD camera (EM-14830RUBY2; JEOL). The transmission microscopy was performed by Tokai Electron Microscopy, Inc. (Nagoya, Japan).

Light microscopy. Morphological observation of these cultured strains was performed under a light microscope (BX-50, Olympus, Tokyo). Microphotographs were taken with a Canon EOS 5D mk2 digital camera (Canon, Tokyo). One hundred measurements were conducted to calculate the cell width and length of each strain. Specimens of the strain NIES-4383 are kept at Department of Botany, National Museum of Nature and Science (TNS).

Molecular analysis. A $1.5-\mathrm{ml}$ volume of fresh culture material was centrifuged at $10,000 \mathrm{rpm}$ for $5 \mathrm{~min}$ at room temperature. The supernatant was removed, and the cell pellets were kept in a freezer at $-20{ }^{\circ} \mathrm{C}$ until extraction. Total genomic DNA was extracted using an extraction kit (PP-207, Jena Bioscience) in accordance with the manufacturer's instructions. The region from $16 \mathrm{~S}$ rRNA to $5 \mathrm{~S}$ rRNA genes was amplified using the primer sets showed Table $\mathrm{S} 1$. The $\mathrm{rbcL}$ gene was amplified using two primer sets (cx-b, cw-b and Annamia-pre-rbcl-F, Annamia-post-rbcl-r; Table S1). PCR was performed on a Veriti Thermal Cycler (Thermo Fisher Scientific) using 0.25 $\mu 1$ polymerase (Phusion Hot Start Flex DNA Polymerase, BioLabs), $5 \mu 1$ GC Buffer in the polymerase kit, $2 \mu 12.5 \mathrm{mM}$ dNTPS, $14.25 \mu 1$ sterile deionized water, $0.25 \mu 1$ each of 10 $\mathrm{pM}$ concentrations of the forward and reverse primers, and 1 $\mu 1$ of DNA template. The temperature cycling program was as follows: $98^{\circ} \mathrm{C}$ for $30 \mathrm{sec} ; 5$ cycles of $98^{\circ} \mathrm{C}$ for $10 \mathrm{~s}, 70$ to 65 
${ }^{\circ} \mathrm{C}\left(-1.0{ }^{\circ} \mathrm{C}\right.$ per a cycle $)$ for $15 \mathrm{~s}, 72{ }^{\circ} \mathrm{C}$ for $120 \mathrm{~s} ; 30$ cycles of $98{ }^{\circ} \mathrm{C}$ for $10 \mathrm{~s}, 65^{\circ} \mathrm{C}$ for $15 \mathrm{~s}, 72^{\circ} \mathrm{C}$ for $120 \mathrm{~s}$; and a final elongation step of $72{ }^{\circ} \mathrm{C}$ for $7 \mathrm{~min}$. The temperature cycling program using primers, Annamia-fa to fd, was as follows: 98 ${ }^{\circ} \mathrm{C}$ for $30 \mathrm{~s} ; 10$ cycles of $98^{\circ} \mathrm{C}$ for $10 \mathrm{~s}, 67$ to $57^{\circ} \mathrm{C}\left(-1.0^{\circ} \mathrm{C}\right.$ per a cycle) for $15 \mathrm{~s}, 72{ }^{\circ} \mathrm{C}$ for $120 \mathrm{~s} ; 25$ cycles of $98^{\circ} \mathrm{C}$ for 10 $\mathrm{s}, 57^{\circ} \mathrm{C}$ for $15 \mathrm{~s}, 72^{\circ} \mathrm{C}$ for $120 \mathrm{~s}$; and a final elongation step of $72{ }^{\circ} \mathrm{C}$ for $7 \mathrm{~min}$. The concentrations of the amplified products were verified on a $1 \%$ agarose gel. Direct sequencing of the PCR products was undertaken using the primers presented in Table S1 with Big Dye Terminator Chemistry and an ABI 3130xl Genetic Analyzer (Applied Biosystems, Foster City, CA). The obtained sequences were assembled using Chromas PRO (Technelysium Pty Ltd, Tewantin, Australia). The assembled results were checked manually after automatic assembly by Chromas Pro. Phylogenetic and molecular evolutionary analyses for the obtained sequences were conducted using the MEGA 7 computer program (KUMAR et al. 2016). The alignments were checked manually. Bayesian inference (BI) with the GTR $+\mathrm{G}+\mathrm{I}$ model was analyzed with MrBayes 3.2.6 (RoNQUIST et al. 2012) for 16S rRNA. Maximum likelihood (ML) with the GTR $+\mathrm{G}+\mathrm{I}$ model method was analyzed using MEGA software. Neighbor joining (NJ) method was analyzed using MEGA software. All positions containing gaps and missing data were partially deleted (site coverage cutoff $70 \%$ ) for ML and NJ methods, and completely deleted for BI method. All sequences used in this study were deposited in the gene bank.

\section{Analysis of microcystins by LC-MS/MS}

Microcystins were analyzed as described (SANO et al. 2016). Briefly, the fresh culture $(0.2 \mathrm{ml})$ was mixed with $200 \mu \mathrm{l}$ of methanol $(\mathrm{MeOH})$ and sonicated in an ultrasonic bath for 10 $\mathrm{min}$. The mixture was filtrated using a $0.45-\mu \mathrm{m}$ membrane filter, and the filtrate was analyzed by liquid chromatography mass spectrometry (LC-MS/MS) with a photodiode array detector (PDA). The LC conditions were follows. Column: Ascentis Express C18 $(2.1 \times 100 \mathrm{~mm}$, particle size $2.7 \mu \mathrm{m}$, Supelco, Bellefonte, PA); solvents: $\mathrm{MeOH}$ gradient $(30 \%-80 \%)$ in 10 $\mathrm{mM} \mathrm{NH} \mathrm{HCOO}_{4}-0.1 \% \mathrm{HCOOH}$ aq.; flow rate: $0.3 \mathrm{ml} / \mathrm{min}$, and column oven temperature: $50^{\circ} \mathrm{C}$. The MS/MS conditions were as follows. Ionization mode: positive ESI, precursor ions: $\mathrm{m} / \mathrm{z} 498.2$ for microcystin-LR, 515.2 for microcystin-FR, 491.2 for microcystin-dmLR; product ion: m/z 135.1 for all variants.

\section{RESULTS}

\section{Taxonomic descriptions}

\section{Chroococcales}

Geminocystaceae Tuji, Yamaguchi et Niiyama fam. nov. Description: Morphologically two types of cyanobacteria, with coccoid cells solitary or in groups and with uniseriate solitary trichomes. Solitary cells spherical to rod-shaped with rounded ends, with or without mucilage, without sheaths, divided by binary fission in one plane or into two perpendicular planes in successive generations. Trichome cells longer than wide, with rounded or flattened apical cells, without sheaths. Thylakoids radial, semi radial, irregular in the transverse plane, and parallel in the longitudinal plane.

Type genus: Geminocystis Korelusová, Kaštovský et Komárek
Other genera in this family are as follows:

\section{Geminobacterium Ramos, Brito et Kaštovský}

Annamia (Nguyen, emend.) Tuji et Niiyama

Revised description: Trichomes solitary, planktic, short or long, uniseriate without false branching, straight or waved, up to $3.5 \mu \mathrm{m}$ wide, without sheaths, motile or immotile. Cells mostly blue-green, long cylindrical or barrel shaped, with scattered granules, without aerotopes. Terminal cells flattened or rounded, without calyptra. Thylakoids arranged radially in the transverse plane, parallelly in the longitudinal plane. Necridic cells, akinetes and heterocytes not observed.

Invalid genus: Cyanobacterium Rippka et Cohen-Bazire Invalid for lacking Latin diagnosis and type.

Table 1 shows Annamia and related genera within Geminocystaceae. KomáreK \& AnAgnostidis (1998) describe eight species of Cyanobacterium based on the morphological characteristics, but only C. stanieri described from cultures PCC7202 is considered.

\section{Annamia dubia Tuji, Yamaguchi et Niiyama sp. nov.} (Figs. 2-3)

Description: Trichomes solitary, planktic, uniseriate without false branching, straight or waved, not constricted at the cross-walls, immotile, without sheaths, 30-40 $\mu \mathrm{m}$ long, but up to several hundred $\mu \mathrm{m}$ long in cluture. Cells blue-green to pale blue-green, with scattered granules, usually long cylindrical, 1.2-3.5 $\mu \mathrm{m}$ wide and 4.6-16.2 (-26.7) $\mu \mathrm{m}$ long, 1.5-11.1 as long as width. Apical cells rounded or flattened. Necridic cells, calyptra, aerotopes, akinetes and heterocytes not observed. Thylakoids peripherally radial in the transverse plane, parallel in the longitudinal plane. Cells produces microcystin.

Holotype here designated: A formaldehyde-fixed specimen, TNS-AL-58964 in TNS (Department of Botany, National Museum of Nature and Science, Japan) from cultured strain NIES-4383 isolated from surface water of Lake Kasumigaura collected on Nov. 11, 2015.

Reference strain: NIES-4383 maintained at the NIES (National Institute for Environmental Studies, Japan). Type locality: Lake Kasumigaura, Ibaraki Pref., Japan. Habitat: Plankton in lakes.

Etymology: the epithet name dubia reflects high morphological variability of trichomes.

Other observation: Carboxysomes are between the thylakoids. Cyanophycin, glycogen granules, and lipid droplets are not observed in culture.

\section{Abundance analyses of genus Annamia using envi- ronmental DNAs \\ Three OTUs, i.e., OTU-70 (LC558222), OTU-8410 (LC558223), and OTU-7201 (LC558224), were selected both as OTUs that are close to the Annamia toxica (GenBank ID: HQ658457; 99.2\%, 99.2\%, and 98.9\% similarity, respectively) and as abundant OTUs among}


the environmental DNAs $(1.1 \%, 0.16 \%$ and $0.14 \%$ of total read abundance within the 36 samples, respectively). OTU-70 was the most abundant of the three OTUs, and the three OTUs showed similar distribution patterns with their peaks during the summer season: July 2012, September 2013, and August 2014 (Fig. 1). However, we have not succeeded in identifying Annamia species using light microscopy for field samples collected from Lake Kasumigaura during 2015.

\section{Morphological and molecular analyses of Annamia dubia sp. nov. (NIES-4383)}

The new species Annamia dubia strain NIES-4383, has 16S rRNA that is very similar to those of the three OTUs (OTU-70, OTU-8410 and OTU-7201) obtained from environmental DNAs (100\%, 98\%, and 97\% similarity), and it is also very close to Annamia toxica strain HOs024 (GenBank ID: HQ658457; seven of 1,281 nucleotides different, $99.5 \%$ similarity). Only one species (A. toxica) was included in this genus so far. Trichomes of $A$. dubia are solitary, blue-green to pale blue-green without sheaths, necridic cells, calyptra and aerotopes, and its cells are usually long cylindrical with scattered granules (just like A. toxica) observed under a light microscope (Fig. 2).

However, there are some differences between A. toxica and A. dubia (Table 2). A. toxica was first reported as Pseudanabaena cf. moniliformis because its trichomes were deeply constricted but the cell dimensions were larger than the original description of P. moniliformis (NGUYEN et al. 2007; NGUYEN et al. 2013). A. toxica shows motility. On the other hand, trichomes of $A$. dubia are straight or waved, partly coiled with variable widths (Fig. $2 \mathrm{~b}-\mathrm{d}$ ), not constricted at the cross walls, immotile, and longer than that of $A$. toxica up to several hundred $\mu \mathrm{m}$ in culture.

The radial thylakoids' arrangement in A. dubia observed by TEM is almost the same as that of $A$. toxica (Fig. 3a-f). In transverse section, the cells are rounded and have peripherally radial rows of thylakoids. No thylakoids are observed in the central part of the cells (nucleoplasm) (Fig. 3a, b). The thylakoids look like swelling or a round shape. Since the swelling or a round shape thylakoids are not only observed in chemical fixation but also observed freeze-substitution method which is less artifact than chemical fixation (data not shown), it should be a natural morphology.

The thylakoids run parallel to the long axis of the trichome (Fig. 3c ). The cell wall has the usual cyanobacterial structure (Fig. 3d). Namely, the cell wall contains layers in the order of the extracellular polymeric substance (EPS), the outer membrane (OM), the peptidoglycan layer (P), and the cell membrane (CM) from the outside. Carboxysomes are present in the vicinity of the thylakoid (Fig. 3e). Polyphosphate granules are scattered in the central part of the cell or the vicinity of the thylakoid (Fig. 3f). Electron clear bodies are scattered in the central part of the cells (Fig. 3f).

The phylogenetic analysis revealed that $A$. 
Table 2. Comparison of Annamia toxica and Annamia dubia sp. nov.

\begin{tabular}{llllllll}
\hline Species & Strain & $\begin{array}{l}\text { Trichome length } \\
(\boldsymbol{\mu m})\end{array}$ & Cell shape & $\begin{array}{l}\text { Cell width } \\
(\boldsymbol{\mu m})\end{array}$ & $\begin{array}{l}\text { Cell length } \\
(\boldsymbol{\mu m})\end{array}$ & $\begin{array}{c}\text { Motility } \\
\text { Thylakoids pat- } \\
\text { tern (transverse } \\
\text { plane) }\end{array}$ \\
\hline A. toxica & HOs24 & $20-229$ & $\begin{array}{l}\text { cylindrical or } \\
\text { barrel-shaped }\end{array}$ & $1.5-3.5$ & $6.3-12.0$ & + & radial \\
A. dubia & NIES- & $\begin{array}{l}30-40 \text { to several } \\
\text { hundreds }\end{array}$ & cylindrical & $1.2-3.5$ & $\begin{array}{l}4.6-16.2 \\
(-26.7)\end{array}$ & - & peripherally radial \\
& 4383 & hund & & & & \\
\hline
\end{tabular}

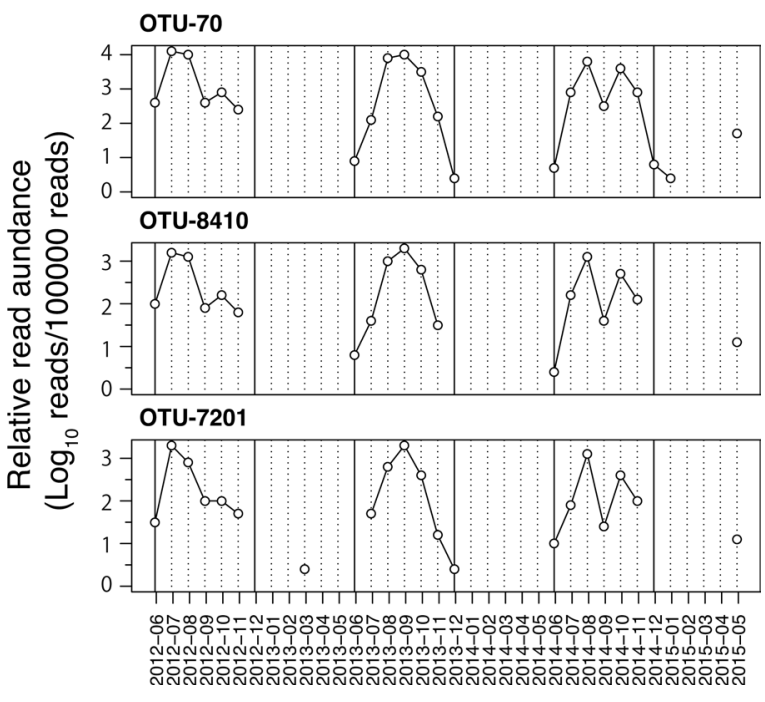

Fig. 1. The seasonal distribution of three abundant and closely relative operational taxonomic units (OTUs) assigned to genus Annamia. The relative read abundance is shown as the $\log _{10}$ value of read abundance per 100,000 reads.

dubia makes a clade with the genera Cyanobacterium, Geminocystis, and Geminobacterium using 16S rRNA (Fig. 4; supported values 99 for BI, 96 for ML and 97 for $\mathrm{NJ}$ ) and rbcL (Fig. 5; supported values 98 for ML and 96 for NJ). Since the length of rbcL sequences deposited in the Genebank are so diverse, BI analysis with MrBayes cannot be applied for rbcL sequences. $A$. dubia also has cpcA and cpcB sequences that are similar to those of $A$. toxica (three of 725 nucleotides different, $99.6 \%$ similarity with HQ658459.1). However, because of the limited numbers of cpcA and cpcB sequences in the GenBank, it is difficult to examine strain $A$. dubia's relationship with other genera using these sequences.

\section{Microcystin analysis}

From Annamia dubia, microcystin-FR (MC-FR) was detected as a major microcystin variant. Microcystin-LR (MC-LR), a small amount of desmethylmicrocystin-LR (dmMC-LR), and one more variant which may be desmethylmicrocystin-FR (dmMC-FR) at $8.2 \mathrm{~min}$ were also detected as minor components (Fig. 6).

\section{Discussion}

During a 3-year eDNA survey, Annamia was abundant every summer season in Japan's Lake Kasumigaura (Fig. 1). Although three Annamia-like OTUs were observed, only one Annamia strain was identified in this study. Two more Annamia taxa might be present in Lake Kasumigaura, but an artificial problem might have made three OTUs from one taxon. Further investigations are needed to address this question.

Though the established Annamia strain is close to Annamia toxica strain HOs024 in 16S rRNA (7 of 1281 nucleotides differences, $99.5 \%$ similarity), the morphology of the new strain is quite different from A. toxica in motility, trichome and cell morphology, and thylakoid pattern (Table 2). We describe a new taxon, Annamia dubia sp. nov. Since $A$. dubia does not agree with the description of genus Annamia described by NGuYen et al. (2013), we revise the description of this genus. Although both taxa A. toxica and A. dubia produce microcystins, this production may not be a characteristic of the genus, because many other cyanobacteria genera such as Microcystis and Dolichospermum produce microcystins.

In addition, the morphological variation of $A$. dubia is very large compared to those of other planktic cyanobacteria, and this makes it difficult to identify A. dubia by light microscopy. We have not succeeded at detecting this species from field samples of Lake Kasumigaura. The morphology of this new species might differ among cells raised under differing culture conditions and/or obtained under various field conditions. If $A$. dubia is composed of a few cells that form a very short trichome in a lake, it may be too difficult to identify it at this time.

The genus Annamia including $A$. toxica and A. dubia makes a monophiletic clade with the genera Cyanobacterium, Geminocystis, and Geminobacterium in 16S rRNA and rbcL phylogeny (Figs. 4, 5). This clade agrees with the phylogenetic tree using 260 housekeeping proteins (MAREŠ et al. 2019: clade 18 in figure 9). The family name of this clade has been confusing. Genus Cyanobacterium Rippka et Cohen-Bazire is described by RIPPKa \& COHEN-BAZIRE (1983) with type species C. stanieri based on strain PCC7202. However, the descriptions of new species and genera are based on the 


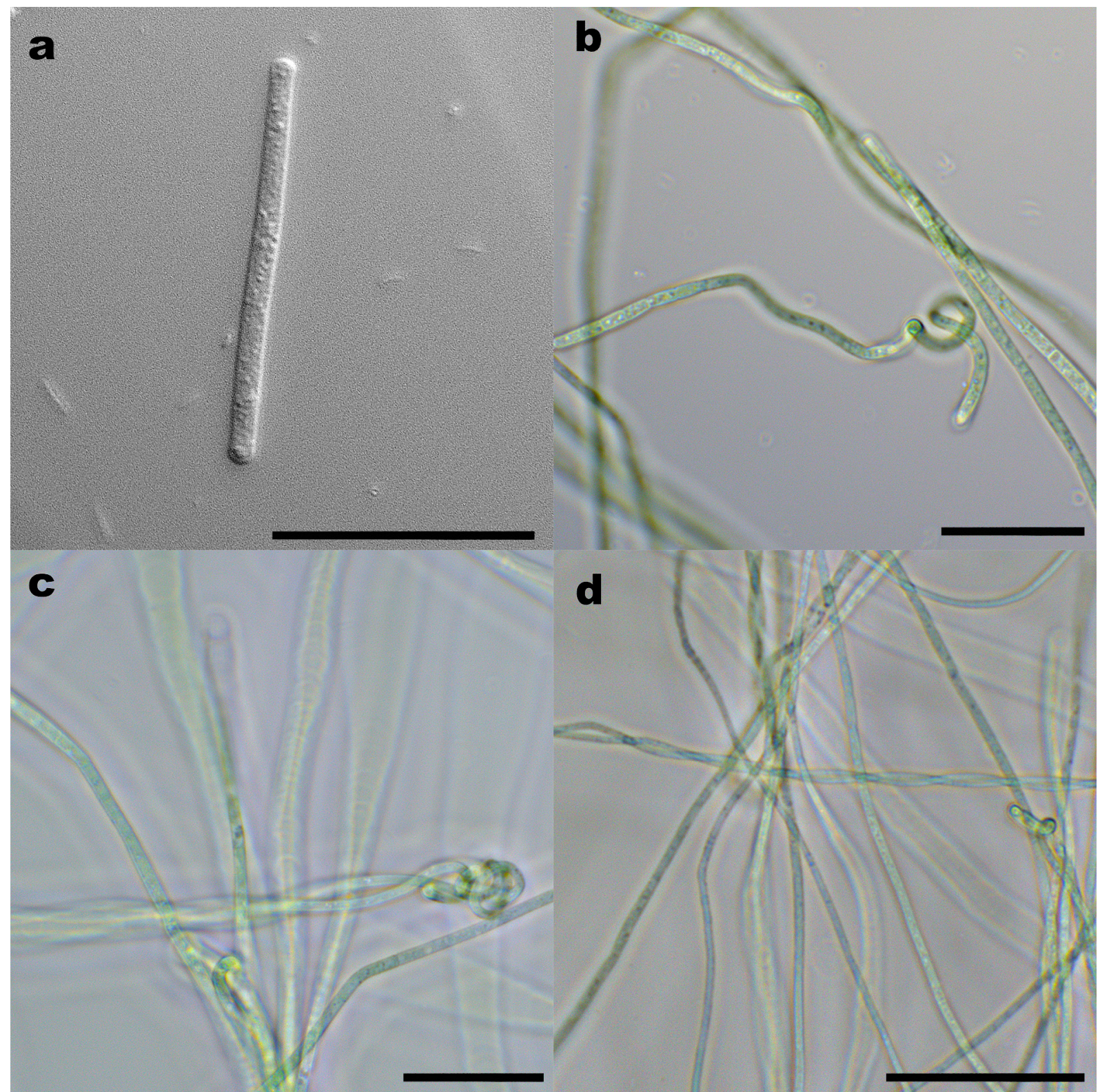

Fig. 2. Annamia dubia sp. nov., light microscopy (LM) micrographs. Scale: $20 \mu \mathrm{m}$.

bacterial code and are invalid in the International Code of Nomenclature for algae, fungi, and plants (ICN). It was also invalid under the previous code (International Code of Botanical Nomenclature: ICBN). KomÁREK et al. (2014: 307) describes the family Cyanobacteriaceae belonging to the order Chroococcales based on the genus Cyanobacterium. However, this family is invalid because of the invalid genus name (ICN Art 18.3). KomáreK et al. (2014: 309) include the genus Annamia in the family Microcoleaceae (Oscillatoriales). HAUER \& KoMÁreK (2020) also assign genus Annamia to the family Microcoleaceae. Recent phylogenetical research using 16S rRNA and 260 housekeeping proteins (MAREŠ et al. 2019: clade 18 in figure 9) suggests that the monophiletic clade with the genera Annamia, Cyanobacterium, Geminocystis and Geminobacterium belongs to the order Chroococcales (BRITo et al. 2017).
These results are against the assignment to the family Microcoleaceae (Oscillatoriales) (Table S2). HAuER \& KomáreK (2020) put the invalid genus 'Cyanobacterium' in the family Chroococcaceae (Chroococcales). If 'Cyanobacterium' belongs to the Chroococcaceae family, all of the members of the monophyletic clade including the genera Annamia, Geminocystis, and Geminobacterium should belong to the same family because of the high supported values of phylogenetic analysis in this study and previous investigations (Table S2). The thylakoid patterns of genus Annamia and 'Cyanobacterium', i.e., radial and parallel, is clearly different from the irregular pattern of Chroococcaceae. In addition, Chroococcaceae have three or more planes for division (KOMÁREK et al. 2014) unlike the genus Annamia including A. dubia, which has only one plane and forms uniseriate trichomes. Chroococcales do not form trichomes, except 

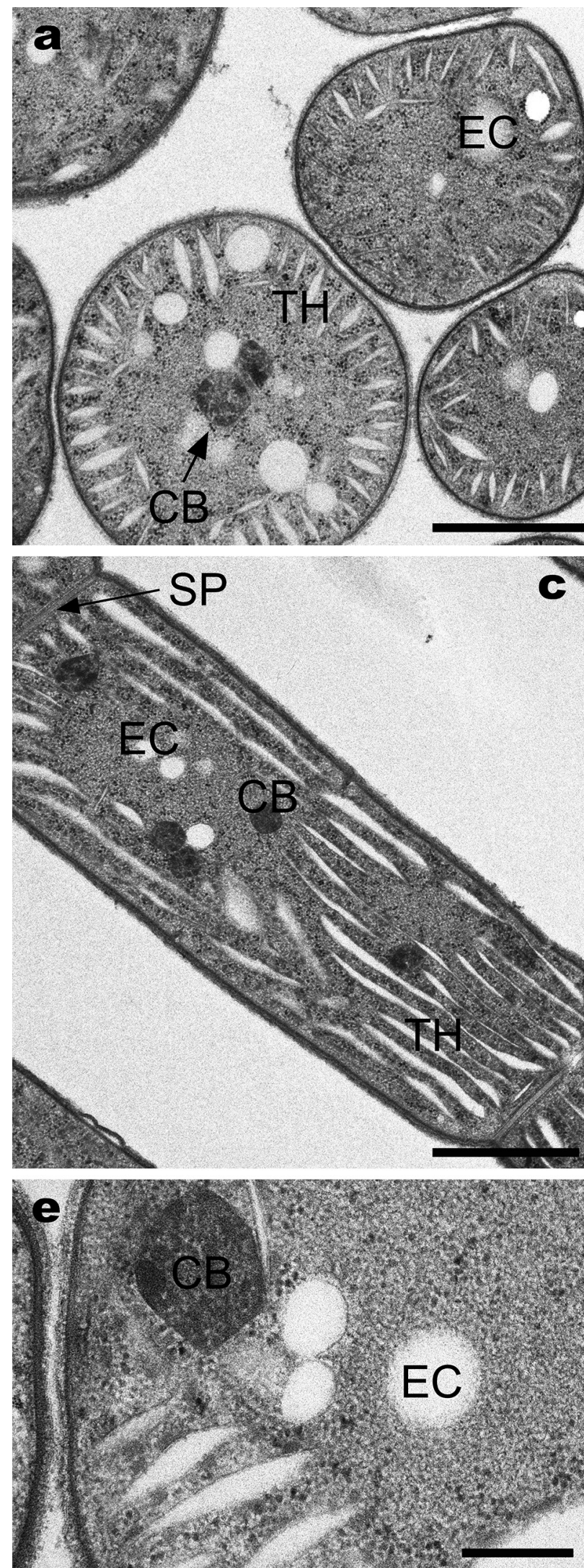

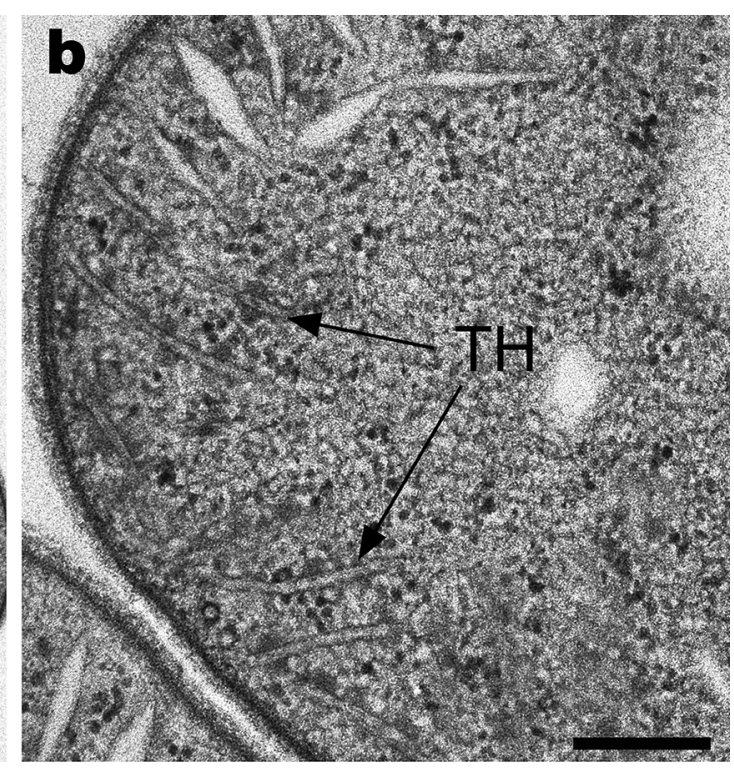

c)
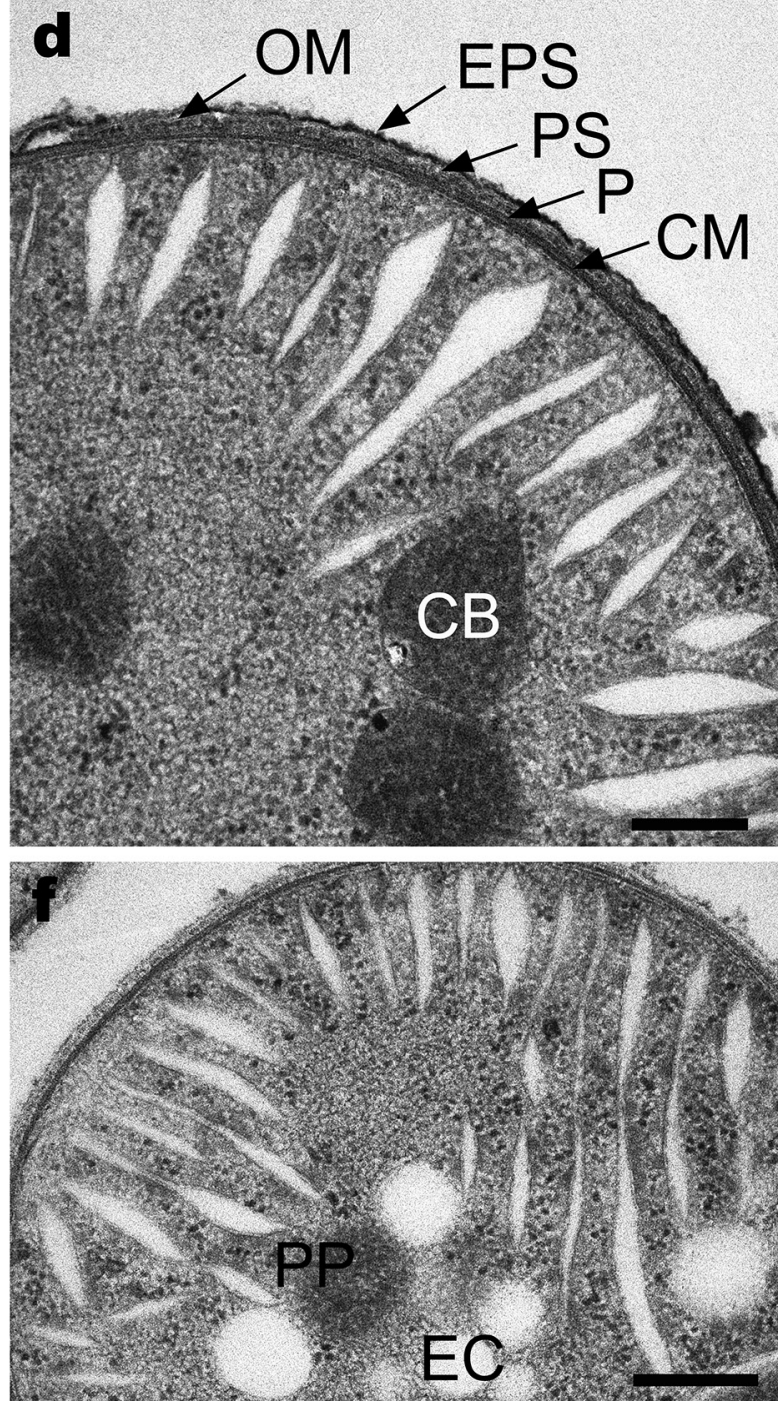

Fig. 3. (a) Annamia dubia sp. nov., TEM, transverse section of the cell showing the radial rows of thylakoids: (CB) carboxysome, (TH) thylakoid, (EC) electron clear body. Scale: $1 \mu \mathrm{m}$; (b) transverse section of the cell with the normal thylakoids. Scale: $200 \mathrm{~nm}$. (c) longitudinal section of the cell. Scale: $1 \mu \mathrm{m}$. (d) transverse section of the cell wall, (CM) cytoplasmic membrane, (E) extracellular polymeric substance (EPS), (OM) outer membrane, (P) peptidoglycan layers, (PS) periplasmic space. Scale: $200 \mathrm{~nm}$. (e) transverse section of the cell with the carboxysome (CB). Scale: $200 \mathrm{~nm}$. (f) transverse section of the cell with the polyphosphate granules (PP) and the electron clear body (EC). Scale: $200 \mathrm{~nm}$. 


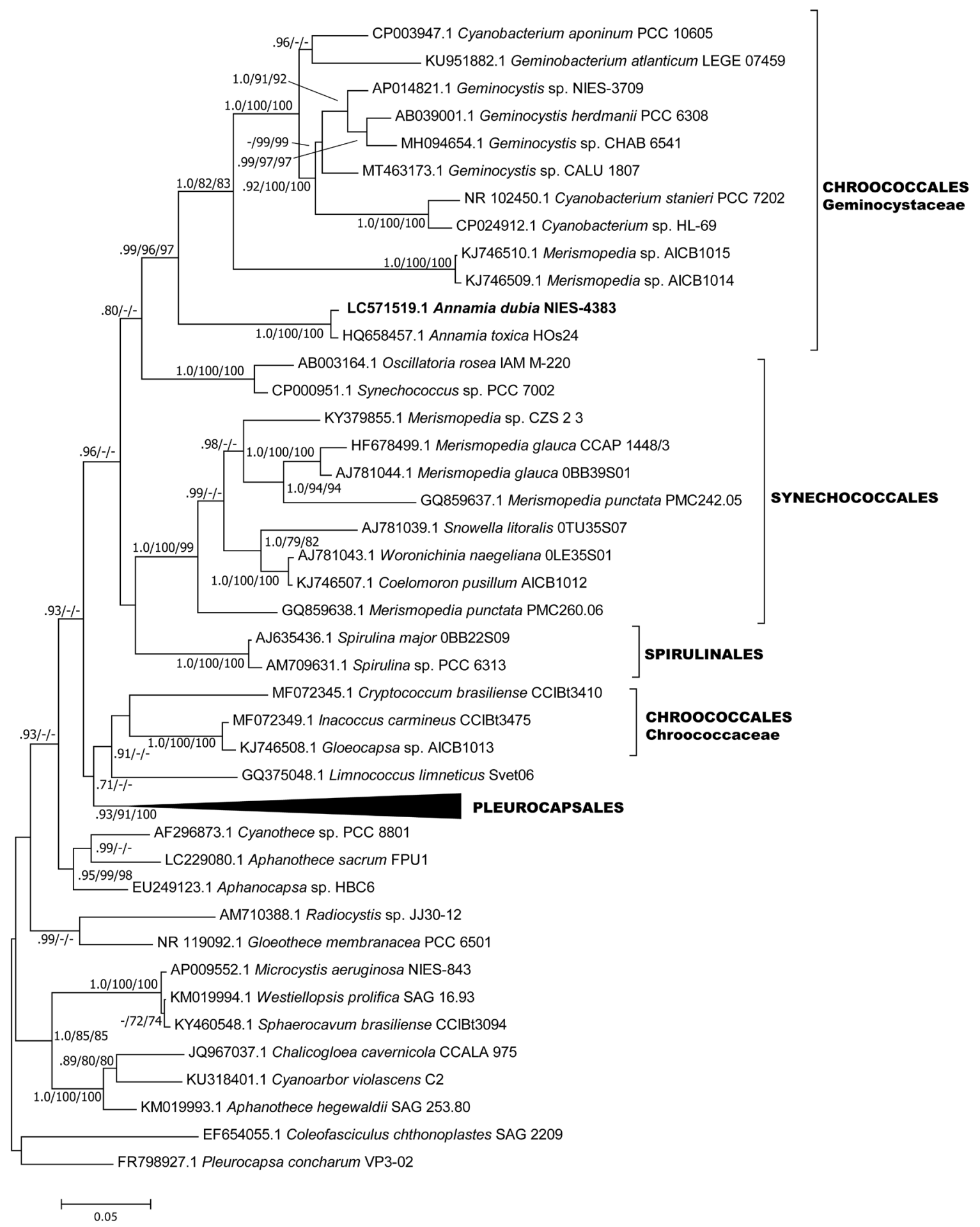

Fig. 4. Bayesian tree (BI) phylogenetic tree based on 136 sequences of the $16 \mathrm{~S}$ rRNA gene and ITS region (1,551 nucleotide positions) showing the structure within the Chroococcales and related orders. Posterior probabilities (PB) with BI and bootstrap support (BS) with ML and NJ methods are indicated at the nodes. A - indicates less than $0.70(\mathrm{~PB})$ or $70 \%(\mathrm{BS})$ support. The novel species is in bold font.

for pseudofilaments for Cyanothrichaceae (HAUER \& KOMÁREK, 2020).

These results require a new family for the monophyletic clade including the genera Annamia, Geminocystis, Geminobacterium, and 'Cyanobacterium' instead of the former term 'Cyanobacteriaceae'. The name 'Cyanobacteria' is used for a Phyllum or a Class and is not related to the genetic name 'Cyanobacterium'. In this case, the name 'Cyanobacteriaceae' should not be used, in order to avoid further confusion. We propose a new family, Geminocysticeae, based on the genus Geminocystis. Annamia is not pseudofilamentous, and the phylogenetic position and the morphology of Annamia are quite unique and very different from other members 


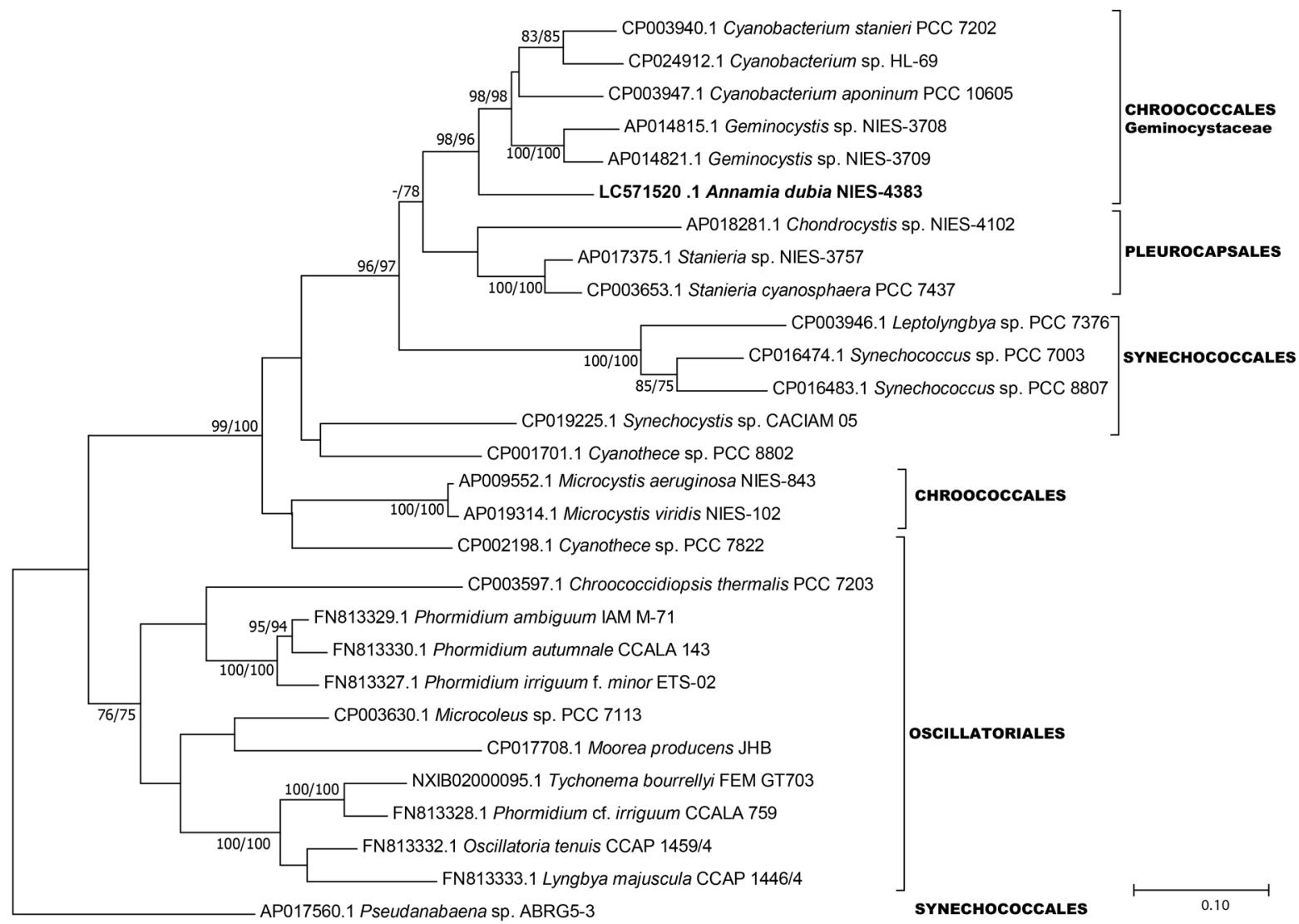

Fig. 5. Maximum likelihood (ML) phylogenetic tree based on 28 sequences of the rbcL gene and ITS region (1,440 nucleotide positions) showing the structure within the Chroococcales and related orders. Bootstrap values greater than $70 \%$ with $\mathrm{ML} / \mathrm{NJ}$ methods are indicated on the tree. The novel species is in bold font.

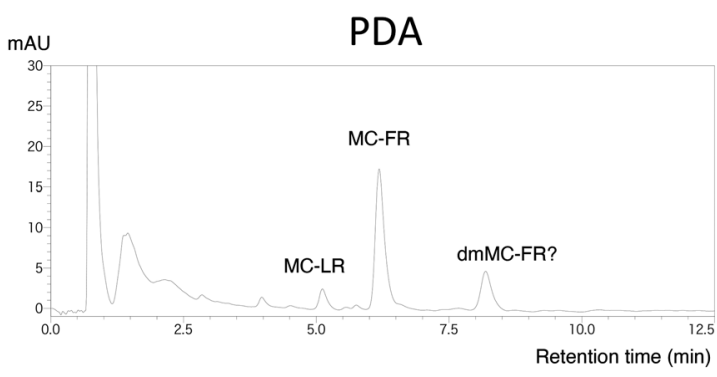

Fig. 6. Microcystin analysis. PDA chromatogram of the extract from Annamia dubia sp. nov. at $238 \mathrm{~nm}$. Column: Ascentis Express C18, $2.1 \times 100 \mathrm{~mm}$, particle size: $2.7 \mu \mathrm{m}$. Solvent A: $10 \mathrm{mM} \mathrm{NH}_{4} \mathrm{HCOO}$ in $0.1 \% \mathrm{HCOOH}$ aq. Solvent B: $\mathrm{MeOH}$; B conc.: $52 \%$; flow rate: $0.3 \mathrm{ml} . \mathrm{min}^{-1}$; column oven temp.: $50{ }^{\circ} \mathrm{C}$. MC-LR: microcystin-LR; MC-FR: microcystin-FR; dmMC-FR: desmethylmicrocystin-FR.

of Chroococcales. The trichome width in $A$. dubia shows irregular changes. This phenomenon is not seen in any member or species of Oscillatoriales, which shows the same width throughout or become narrow or broad at the ends.

\section{ACKNOWLEDGEMENTS}

We thank Prof. Masanobu Kawachi (NIES), Dr. Shuhei Ota (NIES), and Dr. Takeshi Nakayama (University of Tsukuba) for useful comments on
TEM observation. Ms. Megumi Nakagawa (NIES) kindly shared water samples with us. This work was supported by the Lake Kasumigaura Long-term Environmental Monitoring Program of NIES, Japan. This research was partially supported by the National BioResource Project (NBRP) from Japan Agency for Medical Research and Development (AMED) and JSPS KAKENHI Grant Number 20K12201 and 19K15860.

\section{REFERENCES}

Brito, A.; RAmos, V.; Mota, R.; Lima, S.; SANTOS, A.; VieIRA, J.; Vieira, C.P.; KaŠTovskÝ, J.; VASCONCElos, V.M. \& TAMAGNINI, P. (2017): Description of new genera and species of marine cyanobacteria from the Portuguese Atlantic coast. - Mol. Phylogenet. Evol. 111: 18-34.

Hauer, T. \& KomáreK, J. (2020): CyanoDB 2.0 - On-line database of cyanobacterial genera. - World-wide electronic publication, Univ. of South Bohemia \& Inst. of Botany AS CR, http://www.cyanodb.cz.

ICHIMURA, T. (1979): 2. Isolation and culture methods of algae. 2.5.B. Freshwater algae - In: Nishizawa, K. \& ChiHARA, M. (eds): Phycological Studies [Sôrui Kenkyûhô]. pp. 294-305, Kyoritsu Shuppan, Tokyo. (in Japanese)

Korelusová, J.; KašTovskÝ, J. \& KomáreK, J. (2009): Heteroeneity of the cyanobacterial genus Synechocystis and descriptio of a new genus, Geminocystis. - J. Phycol. 45: 928-937.

Kataoka, T.; Yamaguchi, H.; Sato, M.; Watanabe, T.; TANiUChi, Y.; Kuwata, A. \& KawaAChi, M. (2017): Seasonal and geographical distribution of near-surface 
small photosynthetic eukaryotes in the western North Pacific determined by pyrosequencing of $18 \mathrm{~S}$ rDNA. - FEMS Microbiology Ecology 93: 229.

Kato, S. (1982): Laboratory culture and morphology of Colacium vesiculosum Ehrb. (Euglenophyceae). - Jpn.J. Phycol. 30: 63-67.

Kato, T.; Watanabe, M.F. \& Watanabe, M. (1991): Allozyme divergence in Microcystis (Cyanophyceae) and its taxonomic inference. - Algological Studies 64: 129-140.

KomÁreK, J. \& ANAGnostidis, K. (1998): Cyanoprokaryota 1.Teil: Chroococcales. - In: EtTL, H.; GäRTNER, G.; Heynig, H. \& Mollenhauer, D. (eds): Süsswasserflora von Mitteleuropa 19/1. - 548 pp., Gustav Fischer Jena-Stuttgart-Lübeck-Ulm.

KomÁReK, J.; KašTovskÝ, J.; MÁreš, J. \& Johansen, J.R. (2014): Taxonomic classification of cyanoprokaryotes (cyanobacterial genera) 2014, using a polyphasic approach. - Preslia 86: 295-335.

Kumar, S.; Stecher, G. \& Tamura, K. (2016): MEGA7: Molecular Evolutionary genetics analysis Version 7.0 for bigger datasets. - Mol. Biol. Evol. 33: 1870-1874.

Mareš, J.; Strunecký, O.; BuČinská, L. \& Wiedermannové, J. (2019): Evolutionary Patterns of Thylakoid Architecture in Cyanobacteria. - Front. Microbiol. 10: 277.

Nguyen, L.T.T.; Cronberg, G.; Larsen, J. \& Moestrup, Ø. (2007): Planktic cyanobacteria from freshwater localities in Thuathien-Hue Province, Vietnam. I. Morphology and distribution. - Nova Hedwigia 85: 1-34.

Nguyen, L.T.T.; Cronberg, G.; Larsen, J.; Moestrup, Ø. \& DaugBjerg, N. (2013): Annamia toxica gen. et sp. nov. (Cyanobacteria), a freshwater cyanobacterium from Vietnam that produces microcystins: ultrastructure, toxicity and molecular phylogenetics. - Phycologia 52: $25-36$.

Niryama, Y.;Tuji, A.; Takemoto, K. \& Ichise, S. (2016): Pseudanabaena foetida sp. nov. and P. subfoetida sp. nov. (Cyanophyta/ Cyanobacteria) producing 2-methylisoborneol from Japan. - Fottea 16: 1-11.

Rinta-Kanto, J.M.; Ouellette, A.J.A.; Boyer, G.L.; Twiss, M.R.; BRidgeman, T.B. \& Wilhelm, S.W. (2005): Quantification of toxic Microcystis spp. during the 2003 and 2004 blooms in Western Lake Erie using quantitative real-time PCR. - Environ. Sci. Technol. 39: 4198-4205.

Rippka, R. \& CoHEN-BAziRe, G. (1983): The Cyanobacteriales: A legitimate order based on the type strain Cyanobacterium stanieri? - Ann. Inst. Pasteur, Microbiol. 134 B: 21-36.

Ronquist, F.; Teslenko, M.; Vandermark, P.; Ayres, D.L.; Darling, A.; Hohna, S.; Larget, B.; Liu, L.; Suchard, M.A. \& HuelsenBeCK, J.P. (2012): MrBayes 3.2: Efficient Bayesian phylogenetic inference and model choice across a large model space. - Systematic Biology 61: 539-42.

Sano, T.; Tanaka, Y.; Tobishi, K.; Arahori, Y.; A., S.; Sato, C. \& KAYA, K. (2016): A high accuracy and simple analytical method for microcystins using $15 \mathrm{~N}$-labeled microcystins. - Jpn. J. Water Treatment Biology 52: $31-34$.

Shizuka, K.; Ikenaga, M.; Murase, J.; Nakayaa, N.; Matsuya, N.; Kakino, W.; Taruya, H. \& Maie, N. (2020): Diversity of 2-MIB-Producing cyanobacteria in Lake Ogawara: microscopic and molecular ecological approaches. - Aquaculture science 68: 9-23.

TAnabe, A.S. \& ToJu, H. (2013): Two new computational methods for universal DNA barcoding: a benchmark using barcode sequences of bacteria, archaea, animals, fungi, and land plants. - PLoS ONE 8: e76910.

Tuji, A. \& NirYAma, Y. (2016): The identity and phylogeny of Pseudanabaena strain, NIES-512, producing 2-methylisoborneol (2-MIB). - Bull. Natl. Mus. Nat. Sci., Ser. B 42: 1-7.

Tuji, A. \& NiIYAma, Y. (2018a): The taxonomy of Pseudanabaena (Cyanobacteria) and characters for judging the production of odor compounds. - Jpn. J. Water Treatment Biology 54: 115-120.

Tuji, A. \& Niryama, Y. (2018b): Two new Pseudanabaena (Cyanobacteria, Synechococcales) species from Japan, Pseudanabaena cinerea and Pseudanabaena yagii, which produce 2-methylisoborneol. - Phycol. Res. 66: 291-299.

Turner, S.; Pryer, K.M.; Miao, V.P.W. \& Palmer, J.D. (1999): Investigating deep phylogenetic relationships among Cyanobacteria and plastids by small subunit rRNA sequence analysis. - J. Eukaryotic Microbiol. 46: 327-338.

Watanabe, M. (1992): Studies on planktonic blue-green algae 4. Some Anabaena species with straigth trichomes in Japan. - Bull. Natn. Sci. Mus., Tokyo, ser. B 18: 123-137.

Supplementary material

The following supplementary material is available for this article:

Table S1. List of primers used in this study.

Table S2. Comparison of Annamia and related genera.

This material is available as part of the online article (http:// fottea.czechphycology.cz/contents)

(C) Czech Phycological Society (2021)

Received August 4, 2020

Accepted November 29, 2020 